\title{
PENGARUH TEKNOLOGI PENGELASAN PT. CAPUTRA MITRA SEJATI SHIPYARD TERHADAP KUALITAS PEMBANGUNAN KAPAL PATROLI CEPAT (PC) 40
}

\author{
Adhi Susanto ${ }^{1}$, Ferdy Hendarto $\mathrm{S}^{2}$, Priyonggo Syamrahmadi ${ }^{3}$ \\ Magister Terapan Operasi Laut, Sekolah Staf dan Komando TNI AL, Cipulir, Jakarta Selatan 12 \\ Sekolah Staf dan Komando TNI AL, Cipulir, Jakarta Selatan ${ }^{3}$ \\ adhi.susanto@tnial.mil.id
}

\begin{abstract}
Abstrak
Penelitian ini bertujuan untuk mengetahui Pengaruh Teknologi Pengelasan, Keahlian Juru Las dan Perawatan Peralatan Las terhadap Kualitas Pembangunan Kapal Patroli Cepat (PC) 40. Penelitian ini adalah deskriptif kuantitatif dengan 45 responden sebagai sumber data. Teknik analisis data dalam penelitian ini diolah dengan program SPSS versi 25. Hasil penelitian menunjukkan bahwa terdapat pengaruh positif dan signifikan antara Teknologi Pengelasan terhadap Kualitas Pembangunan Kapal Patroli Cepat (PC) 40, terdapat pengaruh positif dan sigfinikan Keahlian Juru Las terhadap Kualitas Pembangunan Kapal Patroli Cepat (PC) 40, dan juga terdapat pengaruh positif dan signifikan dari Perawatan Peralatan Las terhadap Kualitas Pembangunan Kapal Patroli Cepat (PC) 40.
\end{abstract}

Kata kunci: PC 40, Teknologi Pengelasan, Keahlian Juru Las, Perawatan Alat Las

\begin{abstract}
This study was aimed to recognize the effect of welding technology, welder expertise and welding equipment maintenance on the quality of the construction of a Fast Patrol Boat (PC) 40. This study was a quantitative descriptive study with 45 respondents as data sources. The data analysis technique in this study was processed with the SPSS version 25 program. The results showed that there were positive and significant effects of welding technology on the conatruction quality of the Fast Patrol Boat (PC) 40, positive and significant effects of welder expertise on the construction quality of Fast Patrol Boat Development. (PC) 40, positive and significant effects of welding equipment maintenance on the construction quality of the Fast Patrol Boat (PC) 40
\end{abstract}

Keywords: PC 40, Welding Technology, Welder Expertise, Maintenance of Welding Tools

\section{PENDAHULUAN}

TNI AL sebagai komponen pertahanan negara terus mengembangkan dan membangun kekuatannya hingga mencapai kekuatan laut laut (Sea Power) yang profesional serta modern. Sesuai dengan kebijakan pemerintah, TNI AL terus menambah jumlah alutsista salah satunya dengan membangun Kapal Patroli Cepat (PC) 40 di galangan kapal PT. Caputra Mitra Sejati Shipyard.

Pembangunan Kapal Patroli Cepat (PC) 40 tersebut tidak lepas dari kegiatan pengelasan. Terdapat prosedur-perosedur yang harus dipenuhi saat proses pengelasan berlangsung. Terlihat sederhana namun membutuhkan berbagai prosedur yang harus dipenuhi. Ada perbedaan antara pengelasan kapal berbahan alumInium dengan kapal berbahan baja, Sehingga teknologi pengelasan yang digunakanpun berbeda pula.
Kualitas suatu kapal secara konvensional dapat digambarkan salah satunya adalah kapal tersebut memiliki performance, kehandalan, kemudahan dalam penggunaan dan estetika. Kualitas adalah sesuatu yang dapat memenuhi keinginan dan kebutuhan pengguna saat menentukan suatu produk. Terdapat beberapa faktor yang dapat menentukan kualitas pengelesan diantaranya teknologi pengelasan yang digunakan, keahlian juru dan las perawatan las yang digunakan dalam pembangunan sebuah kapal.

Galangan kapal yang berkualitas, modern dan maju akan menggunakan teknologi pengelasan yang mutakhir, menggunakan juru las yang profesional dan sudah bersertifikasi dan merawat alat las yang digunakan guna menghasilkan produk kapal yang berkualitas. Sebuah kapal TNI AL yang berkualitas apabila telah lulus uji Harbour Acceptable Test 
(HAT), Sea Acceptable Test (SAT) dan memperoleh sertifikat kelaikan.

\section{METODOLOGI PENELITIAN}

Metode yang digunakan dalam penelitian ini adalah metode kuantitatif, dimana metode tersebut merupakan metode untuk menguji teori-teori tertentu dengan cara meneliti pengaruh antar variabel dengan instrumen-instrumen penelitian yang telah ditetapkan berdasarkan prosedur statistika.

Data-data yang digunakan dalam penelitian ini ada dua, yaitu data primer dan sekunder. Data primer merupakan data yang diperoleh dari secara langsung dengan metode kuesioner dan diurutkan sesuai skala Likert, sedangkan data sekunder yaitu data yang diperoleh dari buku-buku, jurnal, artikel dan lain sebagainya. Data yang diperoleh diolah menggunakan program SPSS versi 25.

\section{Prosedur Pengambilan data}

Subjek dalam penelitian ini meliputi seluruh personel Satgas Pembanguan Kapal Patroli Cepat (PC) 40, Tim Kelaikan Mabes AL dan Pekerja PT. Caputra Mitra Sejati Shipyard. Teknik pengambilan sampel dalam penelitian ini menggunakan bantuan tabel penentuan sampel. Jumlah sampel diperoleh menggunakan teknik cluster stratified random sampling karena obyek penelitian mempunyai kelompok yang berbeda-beda. Penentuan jumlah sampel menggunakan rumus Slovin adalah sebagai berikut:

$$
n=\frac{N}{\left(N \times e^{2}\right)+1}
$$

Keterangan:

$$
\mathrm{n}=\text { jumlah sampel }
$$

$\mathrm{N}=$ total populasi, jumlah seluruh personel populasi yang terlibat dalam pembangunan

Kapal Patroli Cepat (PC) 40

$\mathrm{e}=$ error tolerance $=0,05$

$$
n=\frac{50}{\left(50 \times 0,05^{2}\right)+1}=44,4
$$

Jumlah sampel sebanyak 44,4 yang kemudian dibulatkan menjadi 45 orang.

\section{ANALISIS DAN PEMBAHASAN DATA}

Pengujian validitas instrumen adalah untuk mengetahui derajat ketepatan instrumen untuk mengumpulkan data penelitian. Pengujian ini dilakukan untuk mengetahui apakah semua pernyataan (instrumen) penelitian yang diajukan untuk mengukur variabel penelitian adalah valid. Jenis validitas yang digunakan dalam penelitian ini adalah construct validity yaitu mencakup pemahaman argumentasi teoritik yang melandasi pengukuran yang diperoleh. Pengujian validitas dengan ketentuan jika $R_{\text {hitung }}$ positif, serta $R_{\text {hitung }}>$

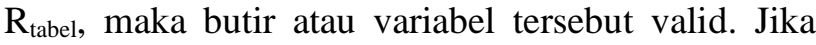
$\mathrm{R}_{\text {hitung }}$ tidak positif, serta $\mathrm{R}_{\text {hitung }}<\mathrm{R}_{\text {tabel}}$, maka butir atau variabel tersebut tidak valid. Analisis uji validitas ini dilakukan dengan cara mengkorelasikan antara skor item dengan skor total item. Nilai $\mathrm{R}_{\text {tabel }}=$ $0.294(\mathrm{n}=45$, maka df $=\mathrm{n}-2=43$ dan alpha $=5 \%)$. Pengujian validitas dengan perhitungan koefisien korelasi Pearson Product Moment, ditemukan seluruh variabel dinyatakan valid. Uji reliabilitas digunakan untuk mengetahui apakah pernyataan yang diajukan terhadap responden akan memberikan jawaban yang cenderung konsisten. Suatu variabel dikatakan reliabel jika memberikan nilai cronbach alpha $\alpha>0.6$

Data yang diperoleh dari penyebaran kuisioner kemudian dianalisis dengan tehnik analisis regresi linier berganda, adapun hasil dari olah data tersebut dapat di sajikan dalam tabel sebagai berikut:

\section{Tabel 1: Hasil Pendugaan Parameter Regresi Linier Berganda}

$$
\begin{aligned}
& \mathrm{Y}=\mathrm{a}+\mathrm{b}_{1} \mathrm{X}_{1}+\mathrm{b}_{2} \mathrm{X}_{2}+\mathrm{b}_{3} \mathrm{X}_{3} \\
& \mathrm{Y}=0.710+0.530 \mathrm{X}_{1}+0.814 \mathrm{X}_{2}+0.814 \mathrm{X}_{3}
\end{aligned}
$$

Berdasarkan pada model persamaan regresi linier tersebut di atas, dapat diinterprestasikan, sebagai berikut:

a. Konstanta (a) $=0,710$

\begin{tabular}{|c|c|c|c|c|c|c|}
\hline \multicolumn{7}{|c|}{ Coefficients $^{\mathrm{a}}$} \\
\hline & \multirow[t]{2}{*}{ Model } & \multicolumn{2}{|c|}{$\begin{array}{c}\text { Unstandardized } \\
\text { Coefficients }\end{array}$} & \multirow{2}{*}{$\begin{array}{c}\begin{array}{c}\text { Standardized } \\
\text { Coefficients }\end{array} \\
\text { Beta } \\
\end{array}$} & \multirow[t]{2}{*}{$\mathrm{t}$} & \multirow[t]{2}{*}{ Sig. } \\
\hline & & $\mathrm{B}$ & Std. Error & & & \\
\hline \multirow[t]{4}{*}{1} & (Constant) & 23,677 & 3,569 & & 6,634 &, 7 \\
\hline & Teknologi Pengelasan &, 865 &, 189 & 633 & 4,566 & \\
\hline & Keahlian Juru Las &, 036 &, 153 &, 033 & 6,237 &, 81 \\
\hline & Perawatan Alat Las & 0,36 & ,153 & ,033 & 6,237 & ,814 \\
\hline
\end{tabular}

Nilai konstanta (a) sebesar 0,710 menunjukkan bahwa, apabila nilai variabel (X) sama dengan nol atau konstan maka besarnya nilai Kualitas Pembangunan Kapal Patroli Cepat (PC) 40 (Y) yaitu

sebesar 0,710. Artinya nilai yang dihasilkan pada kualitas pembangunan Kapal Patroli Cepat (PC) 40 memiliki nilai tetap sebesar 0,710

b. $b_{1}=$ Koefisien Regresi untuk $X_{1}=0.530$

Nilai signifikansi sebesar 0.530 dengan koefisien positif menunjukkan adanya pengaruh yang sesuai antara variabel teknologi pengelasan $\left(\mathrm{X}_{1}\right)$ dengan variabel kualitas pembangunan Kapal Patroli Cepat (PC) 40 (Y). Artinya teknologi pengelasan memberikan nilai kontribusi positif terhadap kualitas pembangunan kapal patroli cepat (PC) 40 sebesar 0,530 .

c. $\mathrm{b}_{2}=$ Koefisien Regresi untuk $\mathrm{X}_{2}=0.814$

Nilai signifikansi sebesar 0.814 dengan koefisien positif menunjukkan adanya pengaruh yang sesuai antara variabel keahlian juru las (X2) dengan 
variabel pembangunan Kapal Patroli Cepat (PC) 40 (Y). Artinya keahlian juru las memberikan nilai kontribusi positif terhadap kualitas pembangunan Kapal Patroli Cepat (PC) 40 sebesar 0,814.

d. $b_{3}=$ Koefisien Regresi untuk $X_{3}=0.814$

Nilai signifikansi sebesar 0.814 dengan koefisien positif menunjukkan adanya pengaruh yang sesuai antara variabel perawatan alat las (X3) dengan variabel pembangunan Kapal Patroli Cepat (PC) 40 (Y). Artinya perawatan alat las memberikan nilai kontribusi positif terhadap kualitas pembangunan Kapal Patroli Cepat (PC) 40 sebesar 0,814.

Untuk menguji hipotesis 1, dan 2, dalam penelitian ini digunakan uji $\mathrm{t}$ yang menunjukkan hubungan secara parsial dari masing-masing variabel bebas terhadap variabel terikat. Uji parsial dimaksudkan untuk mengetahui pengaruh teknologi pengelasan, keahlian juru las dan perawatan alat las terhadap kualitas pembangunan Kapal Patroli Cepat (PC) 40 .

\section{Tabel 2: Hasil Uji t}

\begin{tabular}{|c|c|c|c|c|c|}
\hline \multicolumn{6}{|c|}{ Coefficients $^{\mathrm{a}}$} \\
\hline \multirow{2}{*}{ Model } & \multicolumn{2}{|c|}{$\begin{array}{l}\text { Unstandardized } \\
\text { Coefficients }\end{array}$} & \multirow{2}{*}{\begin{tabular}{|c|}
$\begin{array}{c}\text { Standardi } \\
\text { zed } \\
\text { Coefficie } \\
\text { nts }\end{array}$ \\
Beta
\end{tabular}} & \multirow[t]{2}{*}{$\mathrm{t}$} & \multirow{2}{*}{ Sig. } \\
\hline & B & Std. Error & & & \\
\hline \begin{tabular}{l|l}
1 & (Constant) \\
\end{tabular} & 23,677 & 3,569 & & 6,634 &, 000 \\
\hline $\begin{array}{l}\text { Teknologi } \\
\text { Pengelasan }\end{array}$ & ,865 & , 189 & ,633 & 6,237 &, 000 \\
\hline \begin{tabular}{|l|} 
Keahlian \\
Juru Las
\end{tabular} & ,036 & , 153 & ,033 & 4,566 &, 000 \\
\hline $\begin{array}{l}\text { Perawatan } \\
\text { Alat Las }\end{array}$ & ,036 & , 153 & ,033 & 6,237 &, 001 \\
\hline
\end{tabular}

Teknologi pengelasan yang didapat sebesar 6,237 sedangkan $t_{\text {tabel }}$ yang didapat yaitu sebesar 2,018. Jika $t_{\text {hitung }}>t_{\text {tabel }}(6,237>2,018)$ dan nilai signifikansi $<0,05$, maka dapat diartikan terdapat pengaruh antara teknologi pengelasan terhadap kualitas pembangunan Kapal Patroli Cepat (PC) 40.

Perawatan alat las yang didapat sebesar 6,237 sedangkang $t_{\text {tabel }}$ yang didapat yaitu sebesar 2,018. Artinya jika $t_{\text {hitung }}>t_{\text {tabel }}(6,237>2,018)$ dan nilai signifikansi $<0,05$, maka dapat diartikan terdapat pengaruh antara perawatan alat las terhadap kualitas pembangunan Kapal Patroli Cepat (PC) 40.

Keahlian juru las dari tabel diatas dapat terlihat nilai $t_{\text {hitung }}$ pada variabel keahlian juru las yang didapat sebesar 4,566 sedangkang $t_{\text {tabel }}$ yang didapat yaitu sebesar 2,018. Jika $t_{\text {hitung }}>\mathrm{t}_{\text {tabel }}(4,566$ $>2,018)$ dan nilai signifikansi $<0.05$, maka diartikan terdapat pengaruh antara keahlian juru las terhadap pembangunan Kapal Patroli Cepat (PC) 40.

Uji f (f-Test) untuk mengetahui pengaruh variabel-variabel independen (Teknologi Pengelasan, Keahlian Juru Las dan Perawatan Alat
Las) secara simultan (bersama-sama) terhadap variabel dependen (Kualitas Pembangunan Kapal Patroli Cepat (PC) 40).

\section{Tabel 3: Hasil Uji f}

\begin{tabular}{|l|l|r|r|r|c|c|}
\hline \multicolumn{7}{|c|}{ ANOVA $^{\mathrm{a}}$} \\
\hline \multirow{2}{*}{ Model } & $\begin{array}{r}\text { Sum of } \\
\text { Squares }\end{array}$ & Df & $\begin{array}{c}\text { Mean } \\
\text { Square }\end{array}$ & f & Sig. \\
\hline \multirow{2}{*}{1} & Regression & 276,537 & 2 & 138,268 & 15,427 &, $000^{\mathrm{b}}$ \\
\cline { 2 - 7 } & Residual & 376,441 & 42 & 8,963 & & \\
\cline { 2 - 7 } & Total & 652,978 & 44 & & & \\
\hline
\end{tabular}

Berdasarkan $\mathrm{f}_{\text {tabel }}$ diperoleh angka sebesar 2,83 dan hasil uji f yang didapat sebesar 15,427 (15,427> 2,83 ) dan nilai signifikansi $<0,05$. Menunjukkan bahwa seluruh variabel independen (Teknologi Pengelasan, Perawatan Alat Las dan Keahlian Juru Las) berpengaruh positif dan signifikan terhadap Kualitas Pembangunan Kapal Patroli Cepat (PC) 40.

\section{Tabel 4: Koefisien Korelasi (R) dan Koefisien Determinasi $\left(\mathbf{R}^{2}\right)$}

\begin{tabular}{|c|c|c|c|c|}
\hline \multicolumn{5}{|c|}{ Model Summary } \\
\hline Model & R & R Square & $\begin{array}{l}\text { Adjusted } \\
\text { R Square }\end{array}$ & $\begin{array}{l}\text { Std. Error of } \\
\text { the Estimate }\end{array}$ \\
\hline 1 &, $651^{\mathrm{a}}$ &, 424 &, 396 & 2,994 \\
\hline
\end{tabular}

Nilai koefisien korelasi (R) menunjukkan seberapa erat hubungan antara variabel bebas dengan variabel terikat, besarnya nilai koefisien korelasi adalah 0,651 . Nilai tersebut menunjukkan bahwa hubungan Teknologi Las, Perawatan Alat Las dan Keahlian Juru Las dengan variabel Kualitas Pembangunan Kapal Patroli Cepat (PC) 40 adalah kuat yaitu sebesar $65,1 \%$. Nilai koefisien determinasi atau $\mathrm{R}^{2}$ digunakan untuk mengukur seberapa jauh kemampuan model dalam menerangkan variasi variabel terikat. Hasil dari perhitungan diperoleh nilai $\mathrm{R}^{2}=0,424$ yang berarti bahwa sebesar $42,4 \%$ pembangunan Kapal Patroli Cepat (PC) 40 dapat dijelaskan oleh variabel teknologi pengelasan, keahlian juru las dan perawatan alat las sedangkan sisanya $57,6 \%$ dipengaruhi oleh variabel lain diluar model yang diteliti.

Dengan nilai koefisien korelasi (R) menunjukkan seberapa erat hubungan antara variabel bebas dengan variabel terikat, besarnya nilai koefisien korelasi adalah 0,651. Nilai tersebut menunjukkan bahwa hubungan teknologi las, juru las, perawatan alat las dengan variabel kualitas pengelasan Kapal Patroli Cepat (PC) 40 adalah kuat yaitu sebesar $65,1 \%$.

Menunjukkan nilai koefisien determinasi atau $\mathrm{R}^{2}$ digunakan untuk mengukur seberapa jauh kemampuan model dalam menerangkan variasi 
variabel terikat. Hasil dari perhitungan diperoleh nilai $\mathrm{R}^{2}=0,424$ yang berarti bahwa sebesar $42,4 \%$ kualitas hasil pengelasan Kapal Patroli Cepat (PC) 40 dapat dijelaskan oleh variabel teknologi las, alat las dan perawatan alat las sedangkan sisanya $57,6 \%$ dipengaruhi oleh variabel lain diluar model yang diteliti.

Berdasarkan hasil perhitungan teknologi pengelasan didapat nilai $t_{\text {hitung }}$ pada variabel teknologi pengelasan yang didapat sebesar 6,237 sedangkan $\mathrm{t}$ tabel yang didapat yaitu sebesar 2,018. Artinya jika thitung $>\mathrm{t}_{\text {tabel }}(6,237>2,018)$ dan nilai signifikansi $<0,05$, maka dapat diartikan terdapat pengaruh antara teknologi pengelasan terhadap pembangunan Kapal Patroli Cepat (PC) 40. Sehingga kesimpulannya $\mathrm{H}_{0}$ ditolak dan $\mathrm{H}_{1}$ diterima, hal ini berarti teknologi pengelasan berpengaruh terhadap pembangunan kapal patroli cepat (PC) 40 teruji kebenarannya.

Berdasarkan hasil perhitungan keahlian juru las didapat nilai $\mathrm{t}_{\text {hitung }}$ pada variabel juru las yang didapat sebesar 4,566 sedangkang $t$ tabel yang didapat yaitu sebesar 2,018. Artinya jika $t_{\text {hitung }}>t_{\text {tabel }}(4,566$ $>2,018$ ) dan nilai signifikansi < 0.05, maka dapat diartikan terdapat pengaruh antara keahlian juru las terhadap pembangunan Kapal Patroli Cepat (PC) 40. Sehingga kesimpulannya $\mathrm{H}_{0}$ ditolak dan $\mathrm{H}_{1}$ diterima, hal ini berarti keahlian juru las berpengaruh terhadap pembangunan Kapal Patroli Cepat (PC) 40.

Berdasarkan hasil perhitungan perawatan alat las didapat nilai $t_{\text {hitung }}$ pada variabel perawatan alat las yang didapat sebesar 6,237 sedangkang $\mathrm{t}$ tabel yang didapat yaitu sebesar 2,018. Artinya jika $t$ hitung $>t_{\text {tabel }}(6,237>2,018)$ dan nilai signifikansi $<0,05$, maka dapat diartikan terdapat pengaruh antara perawatan alat las terhadap pembangunan Kapal Patroli Cepat (PC) 40. Sehingga kesimpulannya $\mathrm{H}_{0}$ ditolak dan $\mathrm{H}_{1}$ diterima, hal ini berarti perawatan alat las berpengaruh terhadap pembangunan kapal patroli cepat (PC) 40

\section{SIMPULAN}

Dari analisis data menggunakan program

SPSS versi 25 disimpulkan bahwa:

1. Terdapat pengaruh antara Teknologi Pengelasan terhadap Kualitas Pembangunan Kapal Patroli Cepat (PC) 40. Dapat dilihat dari nilai $t_{\text {hitung }}$ pada variabel Teknologi Pengelasan sebesar 6,237 sedangkan $t_{\text {tabel }}$ yang didapat yaitu sebesar 2,018 . Dengan demikian $t_{\text {hitung }}>t_{\text {tabel }}(6,237>$ 2,018 ) berarti hipotesis yang menyatakan Teknologi Pengelasan berpengaruh terhadap Kualitas Pembangunan Kapal Patroli Cepat (PC) 40 teruji kebenarannya.
2. Terdapat pengaruh antara Keahlian Juru Las terhadap Kualitas Pembangunan Kapal Patroli Cepat (PC) 40. Dapat dilihat dari nilai thitung pada variabel Keahlian Juru Las didapat sebesar 6,237 sedangkan $t_{\text {tabel }}$ sebesar 2,018. Dengan demikian $t_{\text {hitung }}>t_{\text {tabel }}(6,237>2,018)$ berarti hipotesis yang menyatakan Keahlian Juru Las berpengaruh Terhadap Kualitas Pembangunan Kapal Patroli Cepat (PC) 40 teruji kebenarannya.

3. Terdapat pengaruh antara Perawatan Alat Las terhadap Kualitas Pembangunan Kapal Patroli Cepat (PC) 40. Dapat dilihat nilai thitung pada variabel Perawatan Alat Las didapat sebesar 4,566 sedangkan $t_{\text {tabel }}$ yang didapat yaitu sebesar 2,018 . Artinya jika $t_{\text {hitung }}>t_{\text {tabel }}(4,566>2,018)$ berarti hipotesis yang menyatakan Perawatan Alat Las berpengaruh Terhadap Kualitas Pembangunan Kapal Patroli Cepat (PC) 40 teruji kebenarannya.

4. Terdapat pengaruh secara simultan dengan nilai $\mathrm{f}_{\text {tabel }}$ diperoleh angka sebesar 2,83 dan hasil uji $\mathrm{f}$ yang didapat sebesar $15,427(15,427>2,83)$ dan nilai signifikansi $<0,05$. Menunjukkan bahwa seluruh variabel independen (Teknologi Pengelasan, Keahlian Juru Las dan Perawatan Alat Las) berpengaruh positif dan signifikan terhadap Kualitas Pembangunan Kapal Patroli Cepat (PC) 40.

5. Besarnya nilai koefisien korelasi adalah 0,651 atau $65,1 \%$ termasuk dalam kategori kuat. Hasil dari perhitungan diperoleh nilai $\mathrm{R}^{2}=0,424$ yang berarti bahwa sebesar $42,4 \%$ Kualitas Pembangunan Kapal Patroli Cepat (PC) 40 dapat dijelaskan oleh variabel Teknologi Las, Juru Las dan Perawatan Alat Las sedangkan sisanya $57,6 \%$

dipengaruhi oleh variabel lain diluar model yang diteliti.

\section{DAFTAR PUSTAKA}

Perpres No. 5 Th 2010 Tentang Minimum Eficiencial Force (MEF)

Permenakertrans No. 02 Th 1982 Tentang Kualifikasi Juru Las

Alma, Buchari. (2010). Metode dan Teknik Menyusun Tesis. Bandung: Alfabeta.

Arikunto, Suharsimi. (2013) Manajemen Penelitian. Jakarta, Rineka Cipta.

Cresswell, John W. (2013). Research Design: Pendekatan Kualitatif, Kuantitatf dan Mixed. Cetakan III. (Terjemahan Ahmad Fawaid). Yogyakarta: Pustaka Pelajar.

Gaspersz, Vincent. (2001) Total Quality Management. Jakarta: Gramedia. 
Juliansyah, Noor. (2011) Metodologi Penelitian. Kencana: Jakarta.

Riduwan. (2014). Metode dan Teknik Menyusun Tesis. Bandung, Alfabeta.

Sucipto. (2019). Perkuat Armada Perang, TNI AL Bangun Dua Kapal PC 40, diakses tanggal 18 Maret 2020 dari https://nasional.sindonews.com/read/1421696/1 4/perkuat-armada-perang-tni-al-bangun-duakapal-pc-40-1563481635

Sugiono. (2012). Metodologi Penelitian Pendidikan. Bandung: Alfabeta.

Sugiono. (2015). Metode Penelitian Kuantitatif Kualitatif dan $R \& D$ Bandung: Alfabeta.

Sujarweni dan Endrayanto. (2012) Statistika untuk Penelitian Yogyakarta: Graha Ilmu. 